SERGEJ TEŽAK, Ph.D.

E-mail: sergej.tezak@uni-mb.si

University of Maribor, Faculty of Civil Engineering

Smetanova 17, SI-2000 Maribor, Republic of Slovenia

ZDRAVKO TOŠ, Ph.D.

E-mail: tosz@fpz.hr

IVO JURIĆ, M.Sc.

E-mail: jurici@fpz.hr

University of Zagreb

Faculty of Transport and Traffic Sciences

Vukelićeva 4, HR-10000 Zagreb, Republic of Croatia
Transport Engineering Original scientific paper Accepted: July 20, 2009 Approved: May 17, 2010

\title{
RELIABILITY ANALYSIS OF OPERATION FOR CABLEWAYS BY FTA (FAULT TREE ANALYSIS) METHOD
}

\begin{abstract}
This paper examines the reliability of the operation of cableway systems in Slovenia, which has major impact on the quality of service in the mountain tourism, mainly in wintertime. Different types of cableway installations in Slovenia were captured in a sample and fault tree analysis (FTA) was made on the basis of the obtained data. The paper presents the results of the analysis. With these results it is possible to determine the probability of faults of different types of cableways, which types of faults have the greatest impact on the termination of operation, which components of cableways fail most, what is the impact of age of cableways on the occurrence of the faults. Finally, an attempt was made to find if occurrence of faults on individual cableway installation has also impact on traffic on this cableway due to reduced quality of service.
\end{abstract}

\section{KEYWORDS}

cableways, aerial ropeways, chairlifts, ski-tows, quality, faults, fault tree analysis, reliability, service quality, winter tourism, mountain tourist centre

\section{INTRODUCTION}

Cableway traffic, as one of the subsystems of national traffic system, occupies in this system a specific position and place. It allows very efficient mobility and relatively easy accessibility to those parts of nature that are more difficult to reach. The cableway traffic operates using different cable vehicles, which have in common different forms of devices to transport passengers, hauled mainly by cables. Cableways represent a very important part of the tourist offer in the Republic of Slovenia and the quality of their operation is therefore of great importance. Their operation is most significant precisely in the winter ski tourism.
The efficiency of cableway traffic system depends, the same as in other catering activities, on the users' passengers' - satisfaction. The satisfaction of passengers depends on the quality of service that has been provided. The quality of services and passenger cableway transport safety at sport tourist centres is closely related to its reliable and safe operation. The level of safety and reliability of the entire cableway system is greatly affected by the occurrence of faults during its operating hours. This segment of affecting the quality of cableway traffic is still considered with insufficient attention in Slovenia. The object of research is the occurrence of faults and their causes and what influence they have on the transport of passengers in Slovenian cableway traffic.

\section{PASSENGER TRANSPORT PROCESS IN CABLEWAY TRAFFIC}

Systemic study of cableway transport of passengers is significant in order to improve and maintain the quality of the transport service. Figure 1 shows this process schematically, with individual procedures and different possible connections among them, as e.g. different lengths and travelling modes of individual clients - passengers, response and operation method of the cableway company as well as information flows, which need to be analysed.

Systemic monitoring of the provision of services is necessary for high-quality analysis of different disturbances, which occur during operation. The process itself includes all the important activities that are performed during the operation of the cableway companies. Based on the systemic approach presented and studied in such a way, in the analysis and synthesis of different working processes in cableway service reali- 


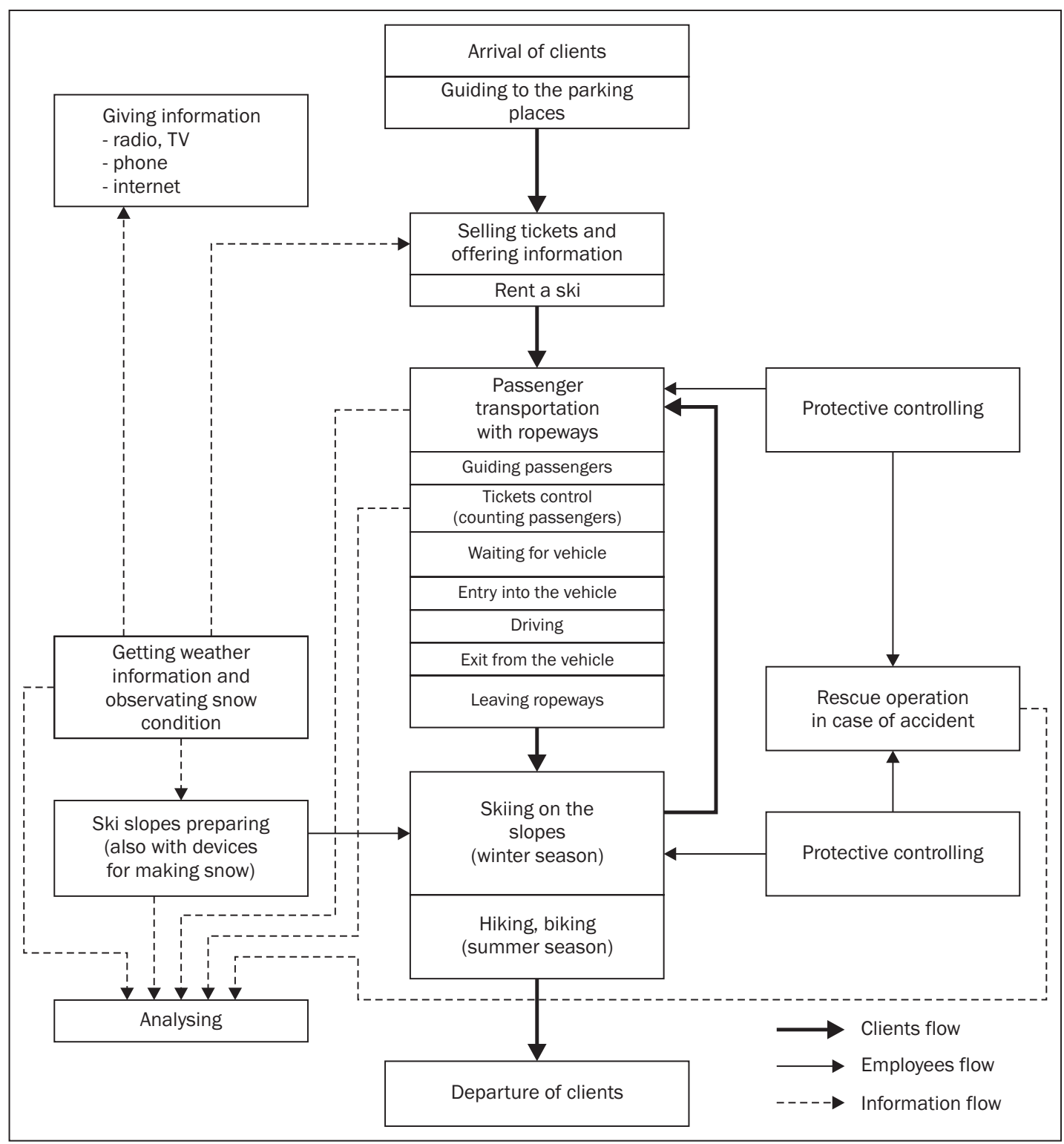

Figure 1 - Process of cableway transportation service

sation phases, it is possible to forecast in advance the disturbances, that may occur in the operation process presented in Figure 2.

\section{RESEARCH METHOD}

The FTA (Fault Tree Analysis) method is used in different technical disciplines as the primary method to determine the reliability and availability in technological systems. The fault tree is a logical map of occurrences, which illustrates the links among undesired events at the level of the entire system and their causes at lower levels of the studied systems. The fault tree method consists of four steps:

- system analysis, where the system is divided into subsystems (components) and the flow chart is developed;
- determining the undesired events - determining the scope of analysis;

- analysis of cause-effect links;

- determining the types of faults (primary, command, secondary fault).

The fault tree method is divided into qualitative and quantitative analyses.

\subsection{Qualitative analysis}

It starts with the determination of the main undesired event. The direct causes of this undesired main event are linked with the main event into an appropriate combination by means of AND or OR gates. The procedure is repeated all the way to the basic or elementary faults. 


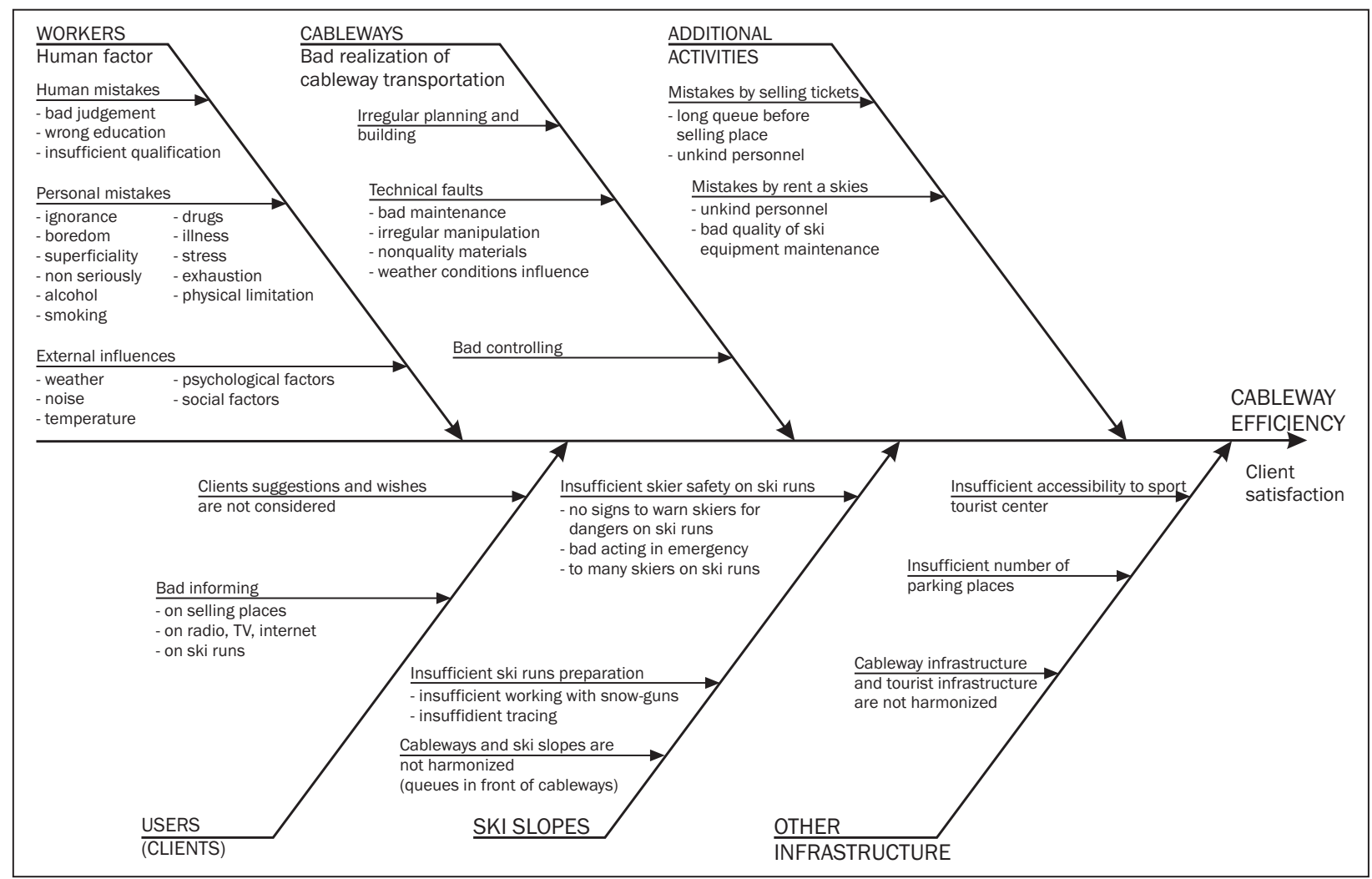

Figure 2 - Disturbances in cableway transportation service process

\subsection{Quantitative analysis}

The probability of occurrence of individual events is used to calculate the number of shutdowns of the entire system. The most important values for the quantitative analysis are reliability or the number of shutdowns that are obtained with the research results or with the behaviour study of single elements or components. These are calculated according to the following equations:

Intensity of faults $\lambda$ :

$$
\lambda(t)=\frac{\text { faults }}{\text { observed time }}
$$

Since the following always holds:

$F(t)+R(t)=1$

then the probability of fault occurrence is:

$F(t)=1-R(t)$

Since $\lambda=$ const., reliability $R(t)$ can be expressed by exponential distribution:

$R(t)=e^{-\lambda t}$

then:

$$
F(t)=1-e^{-\lambda t}
$$

For low values of $F(t)$, it holds that $F(t)=\lambda(t)$

The probability of fault of the observed system:

$S(t)=\sum F(t)$

\section{SAMPLE OF CABLEWAY FAULTS REQUIRED FOR FAULT TREE ANALYSIS}

The required data for analysis have been obtained based on the logbook and interviews with technical heads at individual sport and tourist centres in Slovenia. The data were collected for the period between 1996 and 2006. Only data on faults were collected that caused cableway shutdowns during its operation, which means that the fault caused the shutdown in cableway operation. Here the faults that occurred while the cableway was not operating, i.e. during overhaul, have not been taken into consideration.

For every cableway the following data were collected: name and type of cableway, type of fault that caused the cableway shutdown, year in which the fault occurred, duration of cableway shutdown due to this fault, number of faults in one year, number of cableway operating hours in one year, number of transported passengers per year for individual cableways.

Fifty-eight cableways were taken as a sample, out of which:

- 2 reversible aerial cableways;

- 1 circulating gondola;

- 2 detachable-grip six-seat chairlifts;

- 2 detachable-grip four-seat chairlifts;

- 5 fixed-grip four-seat chairlifts with a loading mobile band;

- 1 fixed-grip three-seat chairlift; 
- 10 fixed-grip two-seat chairlifts;

- 32 ski-tows.

The sample, however, accounts for only $25.4 \%$ of the total number of operative cableways in 2006 . Considering the structure of cableways, then the sample included $50 \%$ cabin lifts, $43 \%$ chairlifts and $18.8 \%$ skitows.

\section{ANALYSIS OF FAULTS ACCORDING TO FAULT TREE METHOD ON CABLEWAYS IN SLOVENIA}

The flowchart in Figure 3 represents a scheme of cableway operation. This flowchart is valid for all the circulating cableways; however, for aerial cableways with bullwheel and funiculars it is valid with certain modifications.

In the period from 1996 to 2006 at 58 studied cableways there were 102,317 faults that caused $5,139.5$ hours $^{1}$ of cableway operation shutdown.

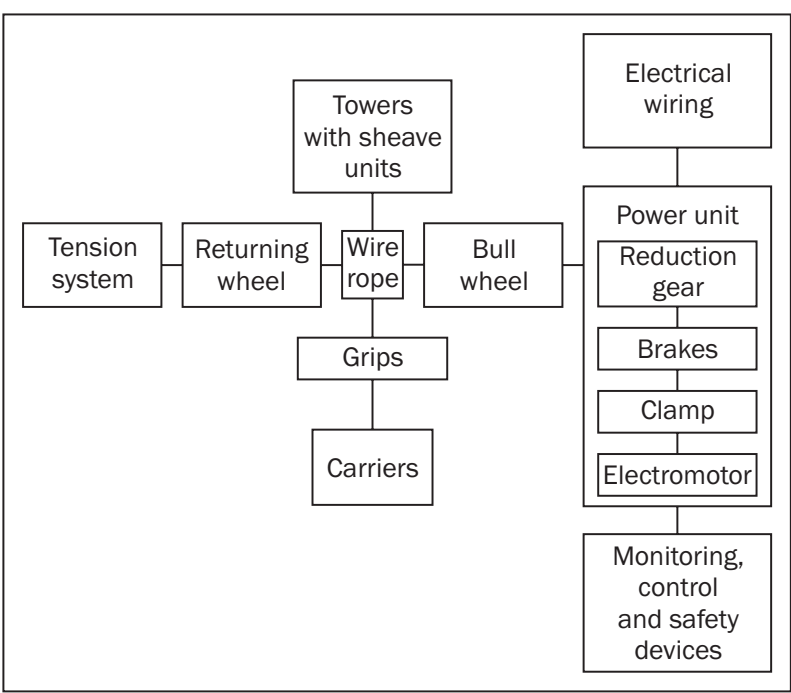

Figure 3 - Block diagram for cableway (system analysis)
In these eleven years these cableways operated for 352,287 working hours.

\subsection{Research results}

The causes of faults may be: human $(72.7 \%$ faults - command faults), obsoleteness or poor quality material (15.4\% faults - primary fault), weather $(11.2 \%$ - secondary faults) and external factor - power failure (0.7\% - secondary faults), which can be seen in Table 1.

Indeed, the number of faults is an important factor for the probability that in the next hour the cableway will malfunction, but for the quality of service the time is also important, for how long the device is not operating due to the fault. In this example, most of the downtime hours are caused by the humans due to their handling or behaviour (35.1\%), obsoleteness or poor quality material (31.9\%), weather conditions (28.6\%) and power failure (4.4\%).

The weather conditions affecting most the faults are: ice (1,184 hours), wind (93.25 hours), snow - excessive snow (27.57 hours) and thunderbolt (10.73 hours). Faults due to temperature difference between the top and bottom station (41.55 hours) affect only one cableway, and therefore this data is not so important for the entire sample of cableways.

Table 2 shows best the occurrence of faults regarding the cableway assembly.

In all types of cableways most faults occurred in electrical devices, and that is on the control devices, control instruments, safety instruments.

Table 2 shows that most faults in cabin lifts are on the grips of reversible cabin lifts, which regularly occurs only on one cableway. Regarding the shutdown duration, prevalent are the faults on the tracks equipment and faults on ropes (one reversible aerial cableway was shut down for several days due to the fault of the carrying rope). Considering the very small sample

Table 1 - Causes of faults, number of faults and cableway shutdown duration from 1996 to 2006

\begin{tabular}{|c|c|c|c|}
\hline & Cause of fault & Number of faults & $\begin{array}{l}\text { Shutdown dura- } \\
\text { tion (hours) }\end{array}$ \\
\hline Humpn & Passenger & 74,280 & $1,606.54$ \\
\hline & Worker & 107 & 198.9 \\
\hline Obsoleteness or poor q & tality material & 15,740 & $1,640.5$ \\
\hline & Humidity & 173 & 109.76 \\
\hline & Ice & 171 & 1,184 \\
\hline & Snow & 26 & 27.57 \\
\hline Meteorological factors & $\begin{array}{l}\text { Temperature difference between } \\
\text { top and bottom station }\end{array}$ & 11,000 & 41.55 \\
\hline & Thunderbolt & 5 & 10.73 \\
\hline & Wind & 14 & 93.25 \\
\hline External factor & Unplanned power failure & 801 & 226.72 \\
\hline TOTAL & & 10,2317 & $5,139.52$ \\
\hline
\end{tabular}


Table 2 - Number of faults and shutdown duration due to fault regarding the cableway assembly in the period from 1996 to 2006

\begin{tabular}{||l|r|c|r|r|r|r|r|r||}
\hline \multicolumn{1}{|c|}{ Component } & \multicolumn{2}{|c|}{ Cabin lifts } & \multicolumn{2}{c|}{ Chairlifts } & \multicolumn{2}{|c|}{ Ski-tows } & \multicolumn{2}{c|}{ All types of cableways } \\
\hline of faults & $\begin{array}{c}\text { Shutdown } \\
\text { duration } \\
\text { (hours) }\end{array}$ & $\begin{array}{c}\text { Number } \\
\text { of faults }\end{array}$ & $\begin{array}{c}\text { Shutdown } \\
\text { duration } \\
\text { (hours) }\end{array}$ & $\begin{array}{c}\text { Number } \\
\text { of faults }\end{array}$ & $\begin{array}{c}\text { Shutdown } \\
\text { duration } \\
\text { (hours) }\end{array}$ & $\begin{array}{c}\text { Number } \\
\text { of faults }\end{array}$ & $\begin{array}{c}\text { Shutdown } \\
\text { duration } \\
\text { (hours) }\end{array}$ \\
\hline \hline Electrical supply & 58 & 28.75 & 276 & 90.69996 & 467 & 104.7697 & 801 & 224.21 \\
\hline Electrical equipment & 217 & 16.354 & 1,042 & 180.5101 & 76,006 & $1,076.969$ & 77,265 & $1,273.83$ \\
\hline Tension system & 0 & 0 & 5 & 1.4164 & 0 & 0 & 5 & 1.41 \\
\hline Line structure & 58 & 162.35 & 88 & 128.5 & 245 & 134.5 & 391 & 425.35 \\
\hline Power unit & 5 & 13.25 & 17 & 108.4933 & 30 & 202 & 52 & 323.74 \\
\hline Station structure & 92 & 18.593 & 9,408 & 90.06866 & 0 & 0 & 9,500 & 108.66 \\
\hline Carrier & 11,000 & 41.55555 & 10 & 70 & 2,238 & 220.292 & 13,248 & 331.94 \\
\hline Rope & 1 & 395 & 0 & 0 & 877 & 841.329 & 878 & $1,236.32$ \\
\hline $\begin{array}{l}\text { Intentional shut- } \\
\text { down due to } \\
\text { weather condition }\end{array}$ & 3 & 9 & 90 & 617 & 84 & 588 & 177 & 1,214 \\
\hline \hline Total & 11,431 & 675.8526 & 10,846 & 669.6884 & 79,863 & $2,579.861$ & 102,317 & $5,139.50$ \\
\hline
\end{tabular}

(3 cableways), one type of fault may have emergency significance and does not therefore render the real picture of the faults.

In case of one-seat chairlifts, the majority of faults are caused by humans - passengers, both on entry and exit from the chairlift (more than 80\%). Regarding shutdown duration, most of the faults are on the mechanical track equipment, electrical devices and power units. The fact is that shutdown times are the longest due to power unit faults.

In case of ski-tows, most of the faults are on electrical devices, when, due to incorrect throwing the towing device is not withdrawn on time thus switching off the safety switch before the sheave. Regarding the shutdown duration, the greatest impact is by the faults on electrical devices and on the ropes, resulting in rope derailment out of the sheave batteries (due to improper usage by skiers).

For each group of cableways the faults tree (Figure 4) was made and it was used to carry out the qualitative and quantitative analyses.

The following example provides data for ski-tows. In the eleven-year period 32 ski-tows operated for 188,023 hours. Within that period there were 79,947 faults which caused $3,167.96$ hours of shutdown on ski-tows, presented in Table 3.

If the data on faults are inserted in equations 3.1, 3.5 , and 3.6, the results of the quantitative faults tree analysis are obtained which are presented in Table 4.

The probability of fault occurrence in case of skitows within one working hour:

$$
\sum F(t)=0.42519
$$

Ski-tow shutdown duration within one working hour:

$$
\sum T(t)=60.655 \text { seconds }
$$

In the same way the faults tree analysis was carried out for cabin lifts and for chairlifts.

For single types of cableways, included in the survey, the results of the quantitative faults tree analysis are best seen in Table 5 .

\subsection{Interpretation of results}

Table 5 shows that the fixed-grip one-seat chairlifts, fixed-grip three-seat chairlifts, four-seat chairlifts without loading band, detachable-grip six-seat chairlifts and reversible aerial cabin lifts feature the highest reliability. In case of these cableways the level of faults in one working hour is lower or equal to 0.008 , which means that in case of these cableways the fault will occur in at least 125 working hours. $(1 / 0.008=125)$.

In these cableways the influence of humans on faults is the lowest. Thus, in one-seat chairlifts the passenger is alone in the seat and does not disturb another passenger since there is no-one beside them. The same holds for the detachable-grip chairlifts since here the passengers are loaded and unloaded at very low speeds of the seat and do not disturb other passengers.

The least reliable of all the types of cableways are chairlifts with loading bank on entry and ski-tows. In case of these cableways humans have the highest influence on the occurrence of faults. These types of cableways have highest speeds of vehicles / towing devices on entry and exit, which is very uncomfortable for the passengers.

For all types of cableways in Slovenia the results of the quantitative faults tree analysis are the following: the probability of cableway fault occurrence in one working hour:

$$
\sum F(t)=0.2904
$$




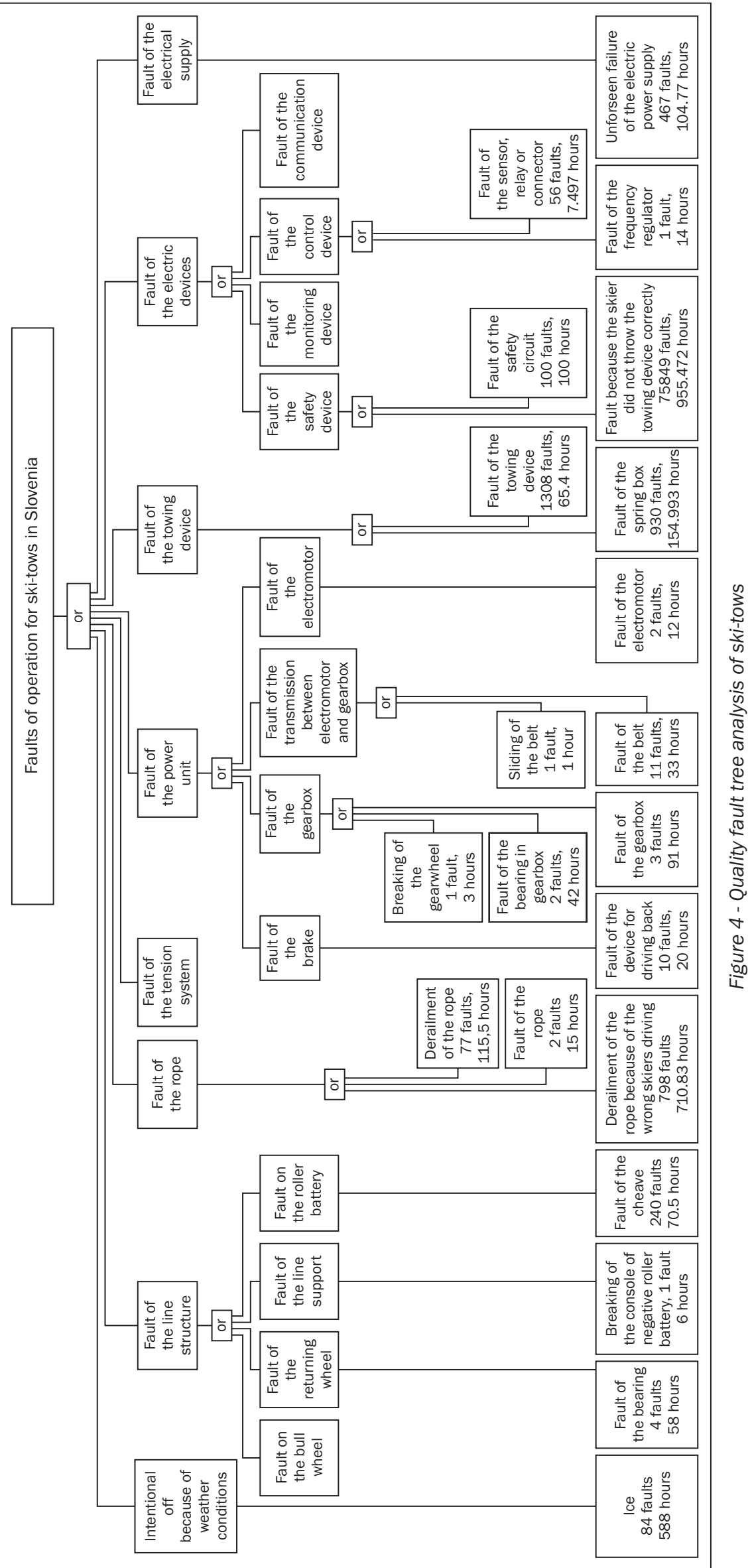


Table 3 - Faults and their causes on ski-tows (1996-2006)

\begin{tabular}{|c|c|c|c|c|}
\hline Component & Fault & Cause & $\begin{array}{l}\text { Number } \\
\text { of faults }\end{array}$ & $\begin{array}{l}\text { Time of the } \\
\text { shutdown-to- } \\
\text { gether (hours) }\end{array}$ \\
\hline Electrical supply & Unforeseen failure of electric power supply & Weather conditions & 467 & 104.7697 \\
\hline \multirow{5}{*}{ Electrical devices } & Fault of the sensor, relay or connector & Fatigue, wear & 56 & 7.497 \\
\hline & Fault of the frequency regulator & Fatigue, wear & 1 & 14 \\
\hline & $\begin{array}{l}\text { Fault because the skier did not } \\
\text { throw the towing device correctly }\end{array}$ & Fatigue, wear & 13,080 & 217.97 \\
\hline & Fault of the safety circuit & Fatigue, wear & 100 & 100 \\
\hline & $\begin{array}{l}\text { Fault because the skier did not } \\
\text { throw the towing device correctly }\end{array}$ & Man - passenger & 62,769 & 737.5022 \\
\hline \multirow{3}{*}{ Line structure } & Fault of the sheave & Fatigue, wear & 240 & 70.5 \\
\hline & Breaking of the console of negative roller & Man - passenger & 1 & 6 \\
\hline & Fault of the bearing & Fatigue, wear & 4 & 58 \\
\hline \multirow{9}{*}{ Power unit } & Fault of the electromotor & Fatigue, wear & 1 & 7 \\
\hline & Fault of the electromotor & Fatigue, wear & 1 & 5 \\
\hline & Sliding of the belt between EM and gearbox & Fatigue, wear & 1 & 1 \\
\hline & Fault of the belt between EM and gearbox & Fatigue, wear & 11 & 33 \\
\hline & Breaking of the gearwheel & Fatigue, wear & 1 & 3 \\
\hline & Fault of the bearing in gearbox & Fatigue, wear & 1 & 21 \\
\hline & Fault of the bearing in gearbox & Man - employee & 1 & 21 \\
\hline & Fault of the gearbox & Fatigue, wear & 3 & 91 \\
\hline & Fault of the device for driving back & Fatigue, wear & 10 & 20 \\
\hline \multirow{2}{*}{ Towing device } & Fault of the towing device & Man - passenger & 1,308 & 65.4 \\
\hline & Fault of the spring box & Fatigue, wear & 930 & 154.9938 \\
\hline \multirow{3}{*}{ Rope } & Derailment of the rope & Man - employee & 77 & 115.5 \\
\hline & Fault of the rope - changing rope & Fatigue, wear & 2 & 15 \\
\hline & $\begin{array}{l}\text { Derailment of the rope because } \\
\text { of the wrong skiers driving }\end{array}$ & Man - passenger & 798 & 710.829 \\
\hline $\begin{array}{l}\text { Intentional operating } \\
\text { off, because of the } \\
\text { weather conditions }\end{array}$ & Off-working because of ice & Weather & 84 & 577 \\
\hline TOTAL & & & 79,947 & $3,167.962$ \\
\hline
\end{tabular}

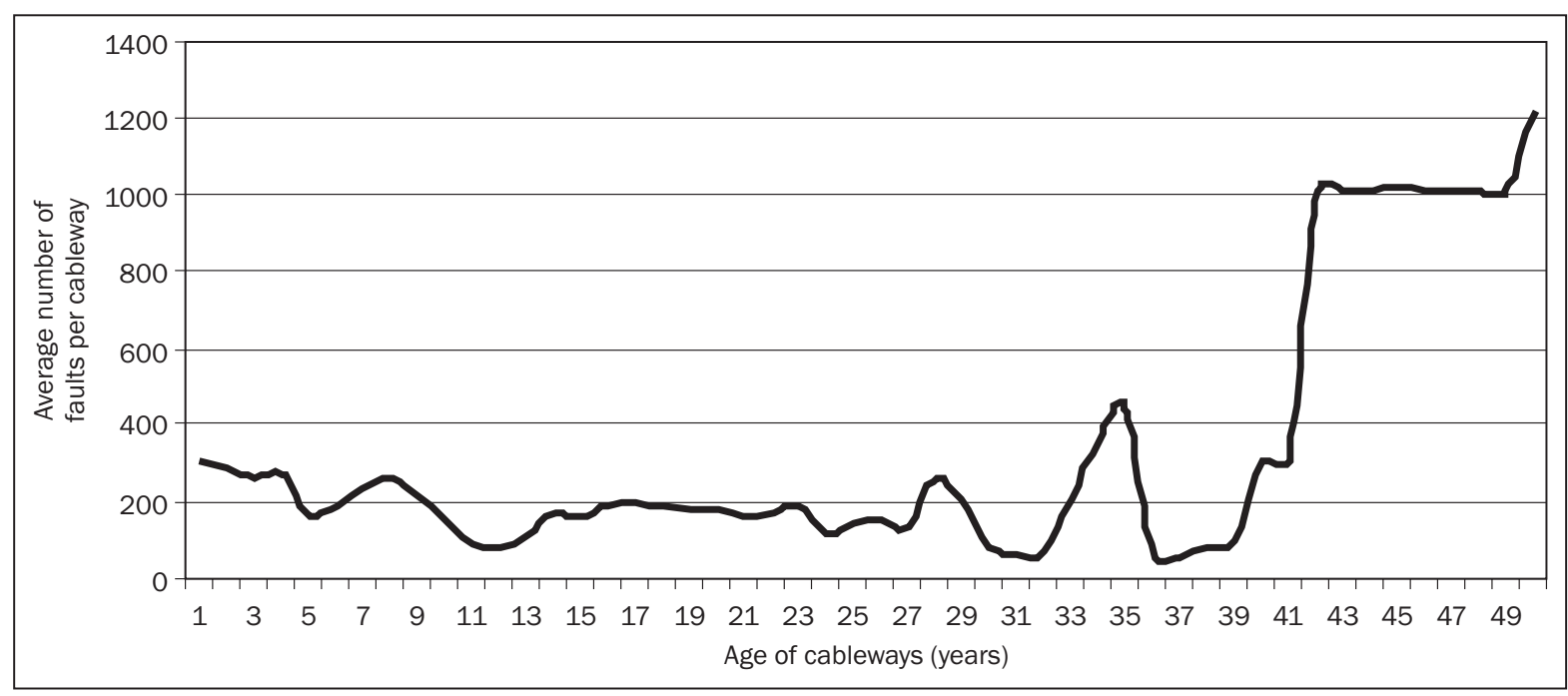

Figure 5 - Average number of cableway faults in a year regarding its age 
Table 4 - Quantitative faults tree analysis for ski-tows

\begin{tabular}{|c|c|c|c|}
\hline Fault & $\begin{array}{c}\text { Failure rate } \\
\text { in one hour } \\
\lambda(\mathrm{t})\end{array}$ & $\begin{array}{c}\text { Probability of } \\
\text { fault in one hour } \\
\text { F(t) }\end{array}$ & $\begin{array}{c}\text { Time of probability } \\
\text { shutdown in } 1 \text { hour } \\
T(t) \text { - seconds }\end{array}$ \\
\hline Unforeseen failure of the electric power supply & 0.00248374 & 0.00248374 & 2.005982885 \\
\hline Fault of the sensor, relay or connector & 0.00029784 & 0.00029784 & 0.143542013 \\
\hline Fault of the frequency regulator & 0.00000531 & 0.00000531 & 0.268052313 \\
\hline Fault because the skier did not throw the towing device correctly & 0.06956596 & 0.06956596 & 4.173383044 \\
\hline Fault of the safety circuit & 0.00053185 & 0.00053185 & 1.914659377 \\
\hline Fault because the skier did not throw the towing device correctly & 0.33383682 & 0.33383682 & 14.12065503 \\
\hline Fault of the sheave & 0.00127644 & 0.00127644 & 1.349834861 \\
\hline Breaking of the console of negative roller & 0.00000531 & 0.00000531 & 0.114879563 \\
\hline Fault of the bearing & 0.00002127 & 0.00002127 & 1.110502439 \\
\hline Fault of the electromotor & 0.00000531 & 0.00000531 & 0.134026156 \\
\hline Fault of the electromotor & 0.00000531 & 0.00000531 & 0.095732969 \\
\hline Sliding of the belt between EM and gearbox & 0.00000531 & 0.00000531 & 0.019146594 \\
\hline Fault of the belt between EM and gearbox & 0.00005850 & 0.00005850 & 0.631837594 \\
\hline Breaking of the gearwheel & 0.00000531 & 0.00000531 & 0.057439781 \\
\hline Fault of the bearing in gearbox & 0.00000531 & 0.00000531 & 0.402078469 \\
\hline Fault of the bearing in gearbox & 0.00000531 & 0.00000531 & 0.402078469 \\
\hline Fault of the gearbox & 0.00001595 & 0.00001595 & 1.742340033 \\
\hline Fault of the device for driving back & 0.00005318 & 0.00005318 & 0.382931875 \\
\hline Fault of the towing device & 0.00695660 & 0.00695660 & 1.252187232 \\
\hline Fault of the spring box & 0.00494620 & 0.00494620 & 2.967603325 \\
\hline Derailment of the rope & 0.00040952 & 0.00040952 & 2.211431580 \\
\hline Fault of the rope - changing rope & 0.00001063 & 0.00001063 & 0.287198907 \\
\hline Derailment of the rope because of the wrong skiers driving & 0.00424416 & 0.00424416 & 13.60995410 \\
\hline Off working because of ice & 0.00044675 & 0.00044675 & 11.25819714 \\
\hline TOTAL & 0.42519798 & 0.42519798 & 60.65567574 \\
\hline
\end{tabular}

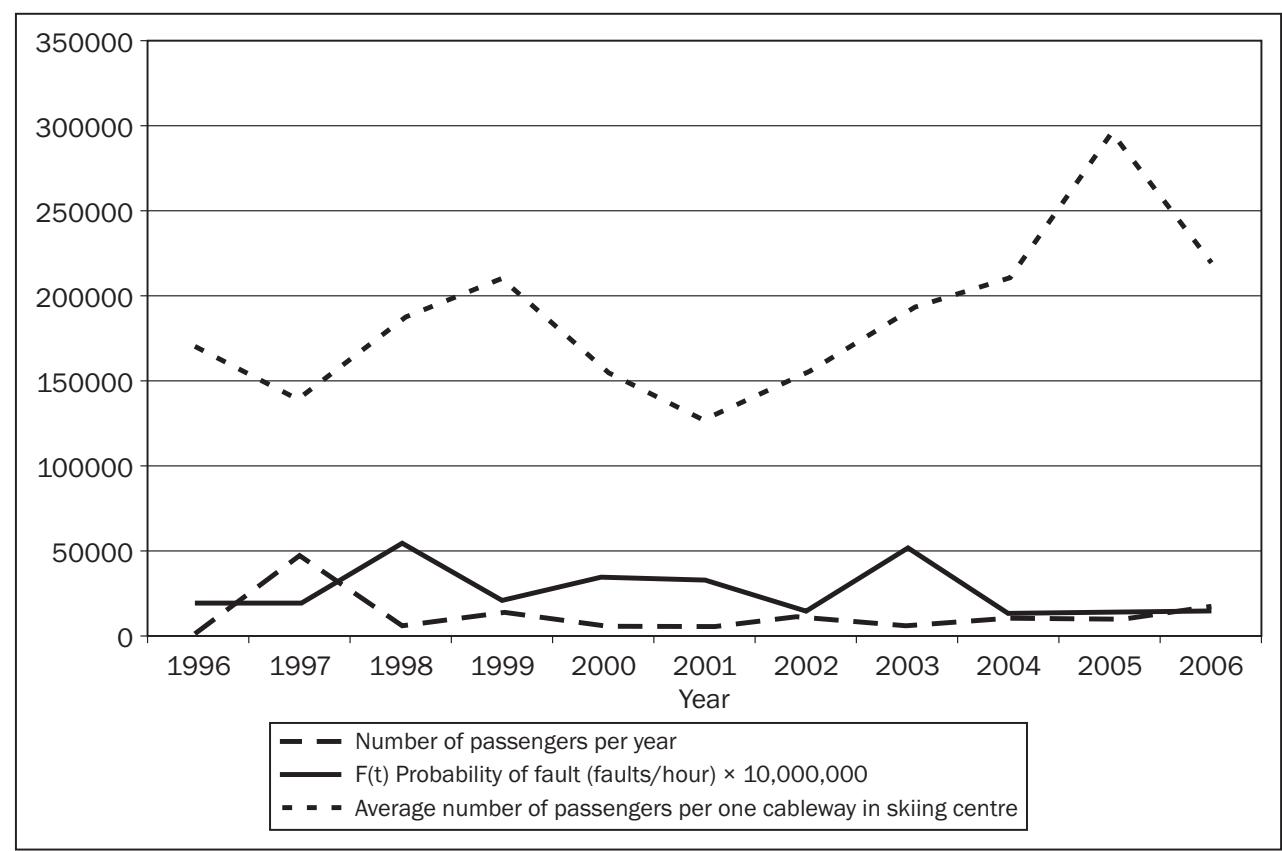

Figure 6 - Probability of fault, number of carried passengers for a one-seat chairlift and average number of carried passengers for a skiing centre cableway 
S. Težak, Z. Toš, I. Jurić: Reliability Analysis of Operation for Cableways by FTA (Fault Tree Analysis) Method

Table 5 - Probability of cableway faults occurrence and shutdown duration within one hour for different types of cableways

\begin{tabular}{||l|c|c||}
\hline \multicolumn{1}{||c|}{ Type of cableway } & $\begin{array}{c}\text { Probability of fault } \\
\text { in one hour } \\
\mathrm{F}(\mathrm{t})\end{array}$ & $\begin{array}{c}\text { Time of probability of } \\
\text { shutdown in 1 hour } \\
\text { T(t) - seconds }\end{array}$ \\
\hline \hline Ski-tows & 0.425197981 & 60.65567459 \\
\hline One-seat chairlifts with fixed grips & 0.004974549 & 101.0990282 \\
\hline Two-seat chairlifts with fixed grips & 0.019374503 & 29.11830283 \\
\hline Three-seat chairlifts with fixed grips & 0.004764293 & 28.43530592 \\
\hline Four-seat chairlifts with detachable grips & 0.007294050 & 15.96338959 \\
\hline Four-seat chairlifts with fixed grips without loading band & 0.008282717 & 7.387852015 \\
\hline Four-seat chairlifts with fixed grips with loading band & 0.673548111 & 40.32766855 \\
\hline Six-seat chairlifts with detachable grips & 0.008029262 & 15.49933446 \\
\hline Gondola lifts unidirectional aerial ropeway & 0.362592132 & 17.89105644 \\
\hline Reversible aerial ropeways & 0.007808143 & 212.4646514 \\
\hline \hline Total chairlifts with fixed grips & 0.108783476 & 42.8807192 \\
\hline Total chairlifts with detachable grips & 0.007621165 & 15.75691978 \\
\hline \hline TOTAL CHAIRLIFTS & 0.088223431 & 37.3681272 \\
\hline TOTAL CABIN LIFTS & 0.283679849 & 61.16878877 \\
\hline TOTAL SKI TOWS & 0.425197981 & 60.65567459 \\
\hline \hline TOTAL - ALL CABLEWAYS & 0.290436491 & 52.520273 \\
\hline \hline
\end{tabular}

the cableway shutdown duration in one working hour:

$$
\sum T(t)=52.5202 \text { seconds }
$$

Regarding the age of cableway, most faults occur in the oldest, and also in the youngest cableways. In case of younger cableways the faults occurrence is often related to the qualification of the personnel and their greater complexity, consisting of several assemblies that may malfunction.

\section{IMPACT OF FAULTS ON CABLEWAY TRAFFIC}

Regarding faults that have caused cableway shutdowns, the question is whether they have influenced the number of carried passengers. The number of passengers carried by cableways depends mostly on the amount of snow at a skiing centre and on other weather conditions. Therefore, it is difficult to establish whether the number of passengers was reduced due to the increase in the number of cableway faults. Regarding the data that were obtained for 58 cableways for 11 years of operation (from 1996 to 2006), it is possible to analyse the dependence between the reduction of the number of carried passengers on the number of faults on single cableways in a season. This analysis can be done based on the following assumption:

- weather conditions (amount of snow, temperature) have the greatest influence on the number of passengers carried by cableways at skiing centres, provided this influence is equal for all the cableways at one skiing centre.
- if in a season the relation between the number of passengers carried by a single cableway and the total number of passengers carried at a skiing centre is reduced, and if at the same time the number of faults or the shutdown duration due to faults on the respective cableway increases, one may conclude that the cause of the reduction in the number of passengers is the increase in the number of faults. This is presented in Figures 6 and 7 for one-seat chairlift. Figure 6 shows the number of the carried passengers and the average number of the carried passengers for the cableway at a skiing centre in the seasons from 1996 to 2006. Moreover the values for the probability of fault have been added (vault/hour).

Figure 7 shows the number of faults in individual seasons, together with the shutdown duration in a single season and the relation between the number of carried passengers according to the number of average carried passengers for the cableway at a skiing centre in which it is located.

These figures show that the faults mostly occurred in the year 1998. In that year (season) the number of the passengers carried on this ski-tow was reduced most, and in the same period the average number of passengers carried by cableway at this skiing centre increased in this year (compared to 1997). This leads to the conclusion that in 1998 it was precisely the cableway shutdowns that were causes for the reduction of the number of the carried passengers. The data for this cableway show that in that year there were faults on the bearings in the shaft, which resulted in several days' shutdown. 


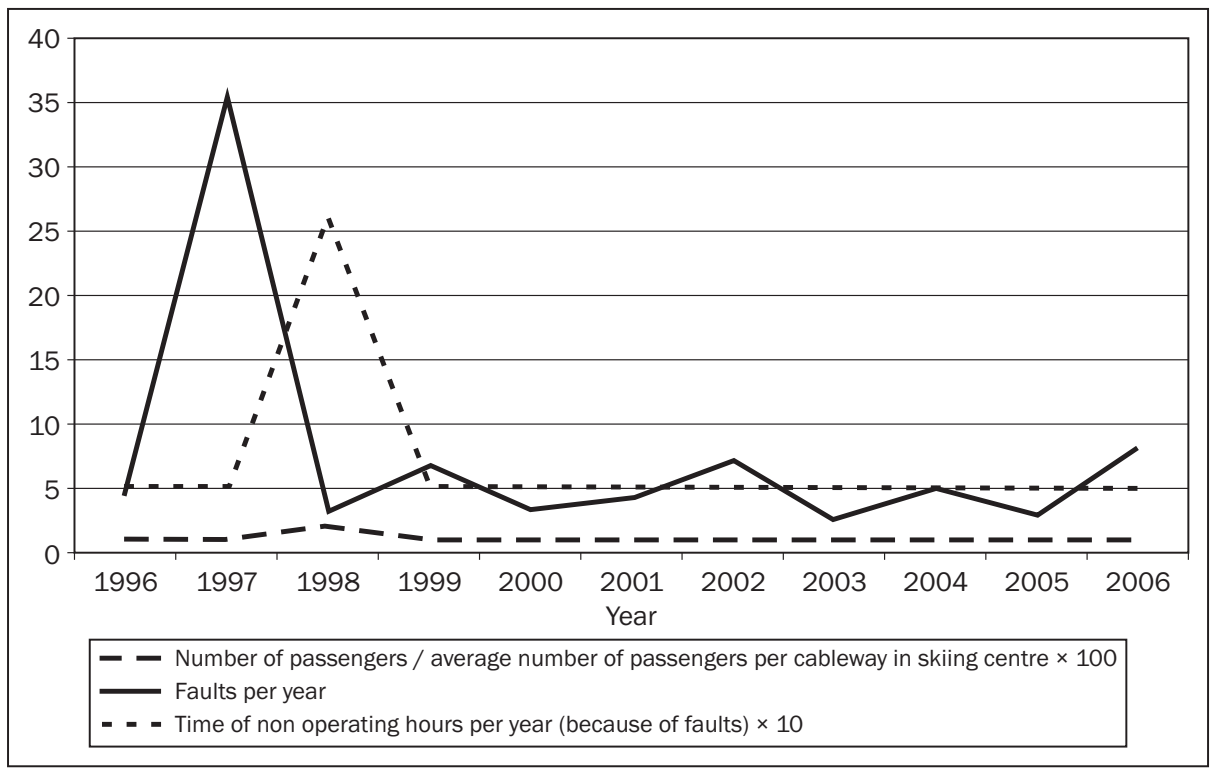

Figure 7 - Number of faults, non-operating hours and relation of carried passengers and average carried passengers for a one-seat chairlift at a skiing centre

Regarding the analysis that was done for all the 58 cableways for which the data on faults and on the traffic were obtained from 1996 to 2006, the influence of faults has been determined on the reduction in the number of carried passengers for 14 cableways and for 22 ski seasons (years). Since 58 cableways in eleven years operated during 638 ski seasons (11 x 58), it may be concluded that the influence of faults on the reduction in the number of carried passengers (skiers) was as little as 3.4\%. (22 out of 638).

\section{CONCLUSION}

The reliability analysis of cableways in Slovenia in the period from 1996 to 2006 has led to the conclusion that the major causes of faults include:

- human influence (passenger and employee $72.7 \%)$;

- obsoleteness or poor quality material (15.4\%);

- meteorological factors (11.2\%);

- power failure and other (0.7\%).

In all types of cableways the biggest cause of faults is the equipment for command, control and safety instruments.

Fixed-grip one-seat chairlifts, fixed-grip three-seat chairlifts, four-seat chairlifts without the loading band, detachable-grip six-seat chairlifts and aerial cabin lifts with reversible aerial ropeways have shown the highest reliability.

Chairlifts with loading band and ski-tows have shown the lowest reliability.

It has been concluded that the impact of faults on the reduction in the number of carried passengers amounted to as little as $3.4 \%$. The probability that a cableway fault would occur within one operating hour is 0.2904 .

\section{Dr. SERGEJ TEŽAK}

E-mail: sergej.tezak@uni-mb.si

Univerza v Mariboru, Fakulteta za gradbeništvo

Smetanova 17, 2000 Maribor, Republika Slovenija

Dr. sc. ZDRAVKO TOŠ

E-mail: tosz@fpz.hr

Mr. Sc. IVO JURIĆ

E-mail: jurici@fpz.hr

Sveučilište u Zagrebu, Fakultet prometnih znanosti Vukelićeva 4, 10000 Zagreb, Republika Hrvatska

\section{POVZETEK}

\section{ANALIZA SIGURNOSTI DELOVANJA ŽIČNIŠKIH NAPRAV PO METODI DREVESA NAPAK}

Članek proučuje sigurnost delovanja žičniških naprav $v$ Sloveniji, katere imajo velik vpliv na kakovost storitev $v$ gorskem turizmu, največ $v$ zimskem času. $V$ vzorec so bile zajete slovenske žičniške naprave različnih vrst in na osnovi pridobljenih podatkov o odpovedi njihovega delovanja je bila narejena analiza drevesa napak (FTA). V članku so predstavljeni rezultati analize s pomočjo katere se je dalo ugotoviti kakšna je verjetnost odpovedi posameznih vrst žičniških naprav, katere vrste napak imajo največji vpliv na odpovedi, kateri sklopi žičniških naprav največkrat odpovedo, kakšen vpliv ima starost žičniških naprav na pojav napak. Na koncu se je poskušalo ugotoviti tudi, ali ima pojav napak na posamezni žičniški napravi tudi vpliv na promet zaradi zmanjšane kakovosti storitve.

\section{KLUČNI POJMI}

žičniške naprave, sedežnice, vlečnice, kakovost, napake, metoda drevesa napak, FTA, zanesljivost, kakovost storitve, zimski turizem, gorsko turistični center 


\section{REFERENCE}

1. Only those faults or impacts are taken into consideration which caused cableway shutdown according to the planned schedule. Faults that were caused outside cableway operating hours have not been considered

\section{LITERATURE}

[1] Ding Y.H., Yu D.T.: Estimation of failure probability of oil and gas transmission pipelines by fuzzy fault tree analysis, Journal of loss prevention in the process industries, Vol. 18, Issue 2, Mar. 2005

[2] Doppelmayr, A.: Denkanstösse zur Funktionserfüllung von Einseilumlaufbahnen, Projektirung und Konstruktion im Sicherheitsregelkreissystem, basierend auf der Analyse von Vorfällen, Wolfurt, September 1997

[3] Gunter, W. A.: Seilbahntechnik, Technische Universität München, München, 1999

[4] Lipičnik, M., Sever, D. et all.: Strokovne podlage za varnost na žičnicah in smučiščih, Faculty of Civil Engineering, Maribor, 2000.
[5] Sever, D.: Some new methods to assure harmonisation of sustainable development of mountain resorts ropeway. Promet, Vol. 14, No. 5, 2002

[6] Šostar, A.: Management kakovosti, Faculty of mechanical engineering, Maribor, 1996.

[7] Težak, S.: Model sustava žičarskog prometa u Sloveniji (Model of the cableway transport system in Slovenia), Ph.D. thesis, University of Zagreb, Faculty of transport and traffic sciences, May 2009

[8] Težak, S.: Service quality and fault analysis in transportation with cableways, V: Soobraćaj i komunikacii $2000=$ Transportation and Communications 2000, 28.-30.09 2000, Ohrid, Makedonija/Macedonia. Soobrak'aj i komunikacii 2000 : strategiski pravci za razvoj : zbornik na trudovi : strategic directions of development: Proceedings. Skopje, 2000

[9] Toš, Z.: Analiza utjecaja vanjskih elemenata na puzdanost žičare "Sljeme", Suvremeni promet, Vol. 10, No. 3, 1988, pp. 275-278

[10] European Parliament and Council Directive relating to cableway installations designed to carry passengers 2000/9/EC, Brussels, May 2000. 
